[18] Mengardo, V., Bencivenga, M., Weindelmayer, J., Pavarana, M., Giacopuzzi, S., de Manzoni, G. (2018). Para-aortic lymphadenectomy in surgery for gastric cancer: current indications and future perspectives. Updates in Surgery, 70 (2), $207-211$. doi: http://doi.org/10.1007/s13304-018-0549-x

[19] Roze, J. F., Hoogendam, J. P., van de Wetering, F. T., Spijker, R., Verleye, L., Vlayen, J. et. al. (2018). Positron emission tomography (PET) and magnetic resonance imaging (MRI) for assessing tumour resectability in advanced epithelial ovarian/ fallopian tube/primary peritoneal cancer. Cochrane Database of Systematic Reviews. doi: http://doi.org/10.1002/14651858. cd012567.pub2

[20] Ong, M. L. H., Schofield, J. B. (2016). Assessment of lymph node involvement in colorectal cancer. World Journal of Gastrointestinal Surgery, 8 (3), 179-192. doi: http://doi.org/10.4240/wjgs.v8.i3.179

\title{
SWOT-ANALYSIS OF MODELS OF ORGANIZATION OF PROVISION OF PRIMARY HEALTH CARE IN THE UNITED TERRITORIAL COMMUNITIES
}

\author{
Grigorii Ursol \\ Department of thoracic and abdominal surgery \\ High Level Certificate thoracic surgeon ${ }^{2}$ \\ Alexandr Skrypnyk \\ Deputy Director of Healthcare department \\ Kirovograd Region State Administration \\ 74 Chmilenko str., Kropyvnytskyi, Ukraine, 25022 \\ uozkir3@ukr.net \\ Olha Vasylenko \\ Department organizational and personnel work ${ }^{2}$ \\ Department of social medicine, regulation and business in Healthcare academic \\ olgeca@i.ua
}

${ }^{1}$ Kharkiv Medicine Academy of postgraduate education of Ukraine's Healthcare Ministry

58 Amosova str., Kharkiv, Ukraine, 61176

${ }^{2}$ Medical centre PE "Hospital of St. Luke"

65 Velyka Perspektivna str., Kropyvnytskyi, Ukraine, 25006

\footnotetext{
Abstract

The article analyzes the strengths, weaknesses, potential opportunities and threats in the process of forming and making appropriate management decisions to integrate health facilities into united territorial communities (UTC) infrastructure, or other options, in the process of decentralization. The basic package of new legislative and regulatory documents has been worked out, which envisages radical changes and systemic reforms, decentralization of power - transfer from the executive bodies to local self-government bodies of a considerable part of powers, resources and responsibilities. A number of reform changes have been identified, which may lead to the expected institutional, organizational and structural-functional changes of the existing public health management system in Ukraine and changes in the individual functional characteristics of the entities of this system. The differences between medical reforms in terms of administrative reform, the role of UTC in this process, in relation to a number of other European countries are considered. On this basis, possible options for the development of events in the context of territorial governance of these processes in the system of health in Ukraine have been proposed. In order to continue scientific research in this direction, the next stage of the evolution of the formation
} 
and adoption of appropriate management decisions in the UTC is to consider the cooperation of the UTC in the creation of joint infrastructure medical facilities, their governing bodies, implementation of projects of activity, financing and maintenance.

Keywords: medical institutions, united territorial communities, SWOT-analysis.

DOI: $10.21303 / 2504-5679.2019 .001052$

\section{Introduction}

When conducting strategic planning of processes related to management, financing, etc., they use various tools that provide analysis of new initiatives, possible changes, promising transformations. In the context of decentralization implemented in Ukraine, the cornerstone is the creation of its own infrastructure of the united territorial communities and the determination of their financial support.

The problem of isolation and further development of the theory and methodology of these processes is of particular relevance due to the fact that many decisions are still being made in Ukraine which lack strategic, systematic and validity.

Significant contribution to the development of institutional and structural transformations in the healthcare sector, including at the community level, contributed by Y. B. Yashchenko, M. V. Shevchenko, Michal Shani (Israel), Francesco Carreli (Italy), D. A. Kuno Vello (Portugal), Sophie San (France) and others.

Foreign studies have noted that the impact of the role of territorial communities on the processes of organizing primary health care to the population is extremely minimized, for which the governments of the countries and the National Health Services are responsible [1]. According to the National Institute for Strategic Studies (Table 1), within the system of territorial organization of health care in EU countries, territorial communities participate mainly in selected Scandinavian countries, Poland, Latvia. In countries such as France, Germany, Italy, Denmark, Czech Republic, Lithuania, Estonia, Romania, Bulgaria, the healthcare system is not within the competence of local self-government bodies of the territorial community $[2,3]$.

Table 1

Participation of territorial communities in the system of territorial organization of healthcare sector in the EU countries

\begin{tabular}{cl}
\hline Country & \multicolumn{1}{c}{ Powers of local self-government bodies of territorial community } \\
\hline Netherlands & $\begin{array}{l}\text { Utility services regulation, territorial development planning, primary education, social protection, health care, } \\
\text { transport, public order, cultural and sports development }\end{array}$ \\
Sweden & $\begin{array}{l}\text { Provision of public utilities, primary education, health care, public transport, local roads } \\
\text { Local commercial and industrial development, primary education, health care, social protection, cultural devel- } \\
\text { opment and leisure }\end{array}$ \\
Poland & $\begin{array}{l}\text { Utility services regulation, social protection and public health, pre-school and primary education, public trans- } \\
\text { port, environmental protection }\end{array}$ \\
Latvia & $\begin{array}{l}\text { Utilities services regulation, health care, primary and secondary education, licensing for commercial activities, } \\
\text { public order and municipal transport }\end{array}$
\end{tabular}

Well-known scientists, as a rule, study the systems and models of organization and financing of the healthcare system, comparing their implementation features in different countries. However, the very issues of conducting medical reform in Ukraine in the context of administrative reform and the role of UTC in this process remain largely unexplored and require in-depth targeted research.

The healthcare industry is currently in the process of systemic institutional and structural-functional transformations, one of which is the ability to create new health care facilities (general medical services (GMS)) in its own UTC infrastructure, or to adopt in the ownership and management of medical facilities, which are currently based in the territories of UTC and are structural units of the territorial centers of GMS (region, city). 
In this regard, in our opinion, it is of great interest to managers, first to UTC managers, to consider different options and models for providing the public with medical care, with an emphasis on determining the position of the owner and manager of funds.

In this study, SWOT analysis was chosen as a tool, a simple but comprehensive strategy that will identify not only the S-strengths and W-weaknesses, the O-opportunities and the T-threats, but also, in combination with other options for analysis, may provide the right direction to make balanced management decisions.

The aim of the article is to investigate the organizational, structural, functional and financial aspects of choosing a primary care organization model in UTC in Ukraine.

\section{Materials and methods}

The methodological basis of this research is a systematic approach, which made it possible to identify the main trends, patterns of development and interconnections of public administration in the healthcare system and public-social relations. Structural and functional approach made it possible to study the dialectic of the structure and functions of the PA system in the healthcare system and to carry out appropriate structuring at different levels according to the main directions and forms of state-administrative activity, in accordance with the stages of implementation of state-administrative decisions. Using the system-situational method made it possible to identify environmental factors, identify resources and stakeholders in the process of remote control in the healthcare system. System-information analysis made it possible to follow the communication processes in the given environment. The comparative analysis provided the theoretical basis for the implementation of foreign experience in the construction and operation of public administration in the health sector in Ukraine. The complexity of the study topic required the use of a number of general scientific (synthesis and analysis, modeling, historical method, etc.) and special methods of scientific knowledge. Among the latter were used etymological analysis and logic-semantic method, which allowed to organize the conceptual and categorical apparatus of the study, to outline the main scientific approaches to the study of the problem.

The analysis of the organizational and legal foundations of the functioning of the public administration system in the healthcare system of Ukraine was carried out taking into account the provisions of the legislative and regulatory framework of Ukraine, and the materials of relevant scientific research.

\section{Results}

The state policy of Ukraine in the field of local self-government is primarily based on the interests of residents of territorial communities and provides for radical changes and systemic reforms, decentralization of power - transfer from the executive authorities to local self-government bodies of a large part of powers, resources and responsibilities. This policy is based on the provisions of the European Charter of Local Self-Government and the world's best standards of public relations in this area.

In April 2014, the Concept of reforming local self-government and territorial organization of government, the Plan of measures for its implementation, which initiated the reform, were approved. Certain political circumstances did not allow the Verkhovna Rada of Ukraine to amend the Constitution on decentralization submitted by the President of Ukraine. Therefore, since 2014, the Government has started reforming the existing Constitution.

Currently, a major package of new legislative and regulatory acts is already in effect, namely: Laws of Ukraine on Amendments to the Budget and Tax Codes of Ukraine, "On the Principles of State Regional Policy" [4], "On Voluntary Association of Territorial Communities" [5], "On Cooperation of Territorial Communities" [6], "On Amendments to Some Legislative Acts of Ukraine on Decentralization of Powers in the Field of Architectural and Construction Control and Improvement of Urban Planning Legislation", relevant decrees of Cabinet of Ministers of Ukraine, administrative documents Minregion, etc..

In the context of these reforms, institutional, organizational and structural-functional changes in the existing public administration (PA) system in the healthcare system in Ukraine and 
changes in the individual functional characteristics of the entities of this system can be expected. UTCs have the ability to:

1) continue to use the services of existing ambulance stations (ASs), rural health posts (RHPs) and feldsher's stations (FSs) operating on the basis of the established model on the basis of the established model. Although there is some legal conflict here - in clause 1.2 "Outpatient clinics" of the order of the Ministry of Health of Ukraine of October 28, 2002, No. 385 "On approving the lists of healthcare institutions, medical, pharmacist positions and positions of junior specialists with pharmaceutical education in institutions health care" (in force) [7] there is a position "Rural health posts (including village and village councils)" and "Rural health posts (including village and village councils)". However, the joint order of the Ministry of Health of Ukraine, the Ministry of Regional Development, Construction and Housing and Communal Services of Ukraine of February 17, 2018 No. 178/24 "On approval of the formation of capable primary healthcare networks" does not provide a rural health posts, as a structural subdivision of health care institutions providing primary health care [8];

2) creation of new medical facilities (primarily GMS facilities) in their own infrastructure;

3) acceptance and ownership of the GMS (AS, RHP, FS) medical facilities, which are currently based in the UTC territories and are structural units of the GMS territorial centers (district, city).

Consideration of the different aspects of the choice of these options (Tab. 2) is the main aim of this study.

Without taking into account the political constituent of UTC, the pre-election promises of UTC chairmen, and the position that each health care facility at different levels is the political capital of both the authorities and territorial political elites, option 1 is most appropriate in the context of ensuring the constitutional rights of UTC residents to obtain basic medical care package. We should take into account that the GMS territorial centers were established in 2013 and already have some experience in providing GMS through the AS, RHP, FS, administration and financing of this system at the level of cities and districts, organization of interaction with other medical institutions and management structures (departments, management, departments of healthcare of different levels of subordination, etc.). The positives of this variant can be attributed to the centralized controlled personnel situation by the head of the GMS center, the possibility of personnel exchanges in each structural unit, the availability of a certain material and technical base of medical institutions, which does not need to spend UTC.

In a political and moral context, the UTC leadership is not formally responsible for the medical care process for the UTC population, but only for the maintenance of the premises owned by the UTC, but does not have direct leverage on the activities of the GMS.

There are practically no real threats to UTC in such a development, because the process of providing medical assistance to the population is organized and purposeful without their participation and responsibility. In 2018, there was still an element of responsibility for the transfer of medical subventions to real medical care providers, which were allocated to UTC each year in a separate line in the Laws of Ukraine "On the State Budget", which was regulated by the Cabinet of Ministers of Ukraine from January 23, 2015 No. 11 "Medical subvention from the state budget to local budgets" (as amended) [9]. Starting in 2019, the financing of GMS facilities in the status of a municipal non-profit enterprise (MNPE) comes at the expense of the NHSU under direct contracts, and these funds no longer go through UTC accounts, but directly through medical institution accounts.

The choice of the 2nd and 3rd variants of models of rendering medical care involves creation of a medical institution in the infrastructure of UTC - a legal entity (medical center, AS, territorial medical association, etc.), ensuring its functioning (administrative, organizational, structural and functional aspects), licensing, accreditation, $100 \%$ staffing according to the equipment plate, staffing (whereby 1 doctor will be the administrator, chief doctor), responsibility for the process of providing medical assistance to the population. These are weaknesses of the process, as it involves significant resource costs (financial, administrative, etc.).

Positive implementation of these models can be attributed to minimizing costs and risks in UTC through outsourcing (outsourcing of non-core activities to an outsourcing organization) and outstaffing. This applies to accounting functions, statistical reporting, personnel accounting and more. 
At the UTC level, such a management option can be implemented by creating a unified management structure (accounting, HR, IT, etc.) for all UTC institutions that will serve them in parallel with the performance of the functions of managing the UTC. Especially in small UTC this can provide work in the areas where it is not possible to attract a certain number of skilled workers (including their substitutions for periods of sickness, vacations, training, etc.), to minimize the costs of arranging jobs (furniture, org. engineering, computer programs, etc.) and their activities (allocation of workplaces, premises, utilities, wages and salaries to employees, etc.). Such an approach will increase competence, manageability, save energy, resources and time, and avoid or minimize the possibility of errors in the performance of these functions and misuse of finances [10, 11].

Establishing a new healthcare facility (legal entity) in UTC or adopting and owning and operating an existing GMS medical facility can create a large pool of risks and threats and require:

- the responsibility of the UTC management for the public health care delivery process (which may not be fully prepared);

- licensing - obtaining a permit for medical practice, drug use, etc. - in accordance with the approved Licensing Conditions (Resolution of the Cabinet of Ministers of Ukraine of March 2, 2016 No. 285 "On Approval of licensing conditions for conducting business activities in medical practice" [12]) subject to $100 \%$ completion of medical equipment, medical devices and medicines, in accordance with the approved Table of equipment (Order of the Ministry of Health of Ukraine dated 26.01.2018 No. 148 "On approval of the Model of logistical equipment of health care institutions and individuals - entrepreneurs who provide the primary medical assistance” [13]), providing the necessary medical personnel;

- ensuring functioning (administrative, organizational, structural and functional aspects) in the absence of experience in such management;

- accreditation (hereinafter) - determining the level of medical facility in the existing system.

The big problem with this model is the complexity of medical staff, given that one doctor must necessarily be the administrator, the chief doctor, which, in a mono practice (having only one doctor), is a very risky moment (Table 2).

A completely different situation with regard to the functioning of the model of primary care in GMS urban centers, where the structure begins and ends with the level of ambulance stations, there are no problems with the long distances and the retention of additional structural units and personnel [14].

There are quite different approaches to these problems in different countries. For example, in Poland, there is a tendency for local governments to lease hospitals for long-term leases at preferential or zero rental rates. There are very few private hospitals in Poland. Outpatient facilities have a different trend. The network of outpatient clinics includes both private and public health facilities. However, most polyclinic public institutions are preparing for privatization [15]. Three components were identified as bottlenecks and inefficiencies: administrative independence of healthcare facilities, tariff-based pricing, and a system with a single national health care provider. It was decided to abandon all this, and all medical institutions would be integrated into a nationwide network managed by the state through territorial centers. And the financing - on the contrary, will be divided into regions, on the principle of subvention. In Ukraine, the primary funding system through the 2018 subventions has been changed to funding through a single national healthcare provider (NHSU). The same model works across different health insurance systems in the UK, Germany (health insurance funds) in Eastern European countries (except Russia, where the health insurance system is virtually inactive, and Belarus, where funding is distributed through the $\mathrm{MOH}$ ). Customers of services (NHSU analogs) pay medical facilities upfront, on the basis of a plan that also includes the unconditional costs of the medical facility (salaries, capital costs, utility and other services to third parties), and the costs directly for the provision of medical services (medicines, tools, content equipment, etc.) [16].

In order to adapt the European reform experience in Ukraine, the U-LEAD (Local Empowerment, Accountability and Development) program is jointly funded by the European Union and its member Denmark, Estonia, Germany, Poland and Sweden. One of the goals of the program is to empower united communities to provide high quality (including medical) services to citizens, contributing to the decentralization reform that is ongoing in Ukraine. 
Table 2

SWOT analysis of primary care organization models in united territorial communities

\begin{tabular}{|c|c|}
\hline $\begin{array}{l}\text { Indicator / } \\
\text { model }\end{array}$ & $\begin{array}{l}\text { Model 1. Use of services of existing AS, RHP, } \\
\text { FS that are in territorial centers of GMS }\end{array}$ \\
\hline S-strengths & $\begin{array}{l}\text { Some experience in providing GMS, organiza- } \\
\text { tion of interaction with other medical institu- } \\
\text { tions and management structures, providing } \\
\text { administration and financing of the system. } \\
\text { Centralized controlled personnel situation, the } \\
\text { possibility of interchangeability. } \\
\text { There is a certain logistical base. } \\
\text { From } 2019 \text { MNPE-funded GMS will be funded } \\
\text { solely by NHSU direct contracts. } \\
\text { The UTC management is not formally responsi- } \\
\text { ble for the medical care process, but only for the } \\
\text { maintenance of the premises owned by UTC }\end{array}$ \\
\hline
\end{tabular}

W-weak- Absence of direct levers of influence on nesses the activity of GMS institutions by the management of UTC

O-opportu- As the owner of the premises, UTC is obliged nities to hold them, to pay for utilities. By good will, UTC can financially support the activities of GMS facilities, stimulate the work of medical personnel and the like

Model 2. Creation of new
medical facilities in its own
infrastructure

Model 3. Acceptance and management of existing AS, RHP, FS

The use of GMS facilities by the UTC's leadership, territorial political elites, as political capital, in the absence of responsibility for the process of organizing medical assistance to the population, may have drawbacks and negative points.

The need to create a legal entity in UTC (medical center, TMO, AS, etc.), to ensure its licensing, accreditation, operation, $100 \%$ staffing according to the equipment plate, providing personnel, UTC's responsibility for the process of providing medical assistance to the population.

Conducting minimization of UTC expenditures through outsourcing and outsourcing of accounting functions, preparation of statistical reports, personnel accounting, etc. (non-core activities).

Decide on incentives for GMS and medical staff to work with UTC's resources and capabilities.

Failure to fully meet certain requirements for the establishment and operation of health care facilities (see "weaknesses"). During the period of illness of the doctor (chief physician), planned leave, vacations at will, business trips, training period, etc. the provision of medical assistance to the UTC population will not be conducted. This may result in NHSU's refusal to pay for this period for the provision of medical services. In the case of a serious illness, death, transfer to another place of residence and work, the absence of the primary physician automatically suspends the activity of the medical institution and the payment of its activity to the NHSU, until the termination of the contractual obligations.

The next stage in the evolution of the formation and adoption of appropriate management decisions regarding the activities of healthcare facilities at UTC is UTC cooperation, which is possible under the following positions: delegation of individual tasks with the transfer of appropriate resources; implementation of joint projects, which involves coordination of activities and accumulation of resources; creation, financing and maintenance of joint infrastructure medical facilities; the formation by the subjects of cooperation of joint management bodies of such objects [17, 18]. This stage may be the subject of further scientific research.

\section{Conclusions}

The study of the organizational, structural, functional and financial aspects of choosing a model of primary care organization in UTC in Ukraine on the basis of SWOT analysis (in combination with other elements of analysis) has led to the conclusion that based on regulatory, organizational and regulatory and programmatic target forms of implementation of public administration decisions, it is currently not advisable to create new medical facilities or take existing medical facilities into ownership and management when conducting institutional changes at UTC establishments GMS. The best model, in our opinion, is the established model of functioning of GMS territorial centers. At the same time, UTC only maintains its own facilities where medical facilities 
are based, and payment for utilities. By good will, UTC can financially support the activities of GMS facilities, stimulate the work of medical personnel and the like.

\section{Conflict of interests}

No conflict of Interest.

\section{References}

[1] Nikolaienko, V. B. (2018). Pervynna medychna dopomoha v «epokhu zmin»: vitchyznianyi ta mizhnarodnyi dosvid. Ukrainskyi medychnyi chasopys, 3 (2 (125)). Available at: https://www.umj.com.ua/article/126600/pervinna-medichna-dopomoga-v-epohu-zmin-vitchiznyanij-ta-mizhnarodnij-dosvid

[2] Terytorialna hromada yak bazova lanka administratyvno-terytorialnoho ustroiu Ukrainy: problemy ta perspektyvy reformuvannia (2016). Kyiv: NISD, 50-54.

[3] Yashchenko, Yu. B., Shevchenko, M. V. (2016). Finansova detsentralizatsiia v systemi okhorony zdorovia. Ekonomika i pravo okhorony zdorovia, 2 (4), 39-43. Available at: http://ekmair.ukma.edu.ua/bitstream/handle/123456789/11703/Shevchenko_ FinansovF_detsentralizatsiia_v_systemi_okhorony_zdorov \%E2 \%80 \%B2ya.pdf?sequence=1\&iisAllowe=y

[4] Pro zasady derzhavnoi rehionalnoi polityky (2015). Zakon Ukrainy No. 156-VIII. 05.02.2015 (iz zminamy). Available at: http:// zakon.rada.gov.ua/laws/show/156-19

[5] Pro dobrovilne obiednannia terytorialnykh hromad (2015). Zakon Ukrainy No. 157-VIII. 05.02.2015 (iz zminamy). Available at: http://zakon.rada.gov.ua/laws/show/157-19

[6] Pro spivrobitnytstvo terytorialnykh hromad (2014). Zakon Ukrainy No. 1508-VII. 17.06.2014 (iz zminamy). Available at: http:// zakon.rada.gov.ua/laws/show/1508-18

[7] Pro zatverdzhennia perelikiv zakladiv okhorony zdorovia, likarskykh, provizorskykh posad ta posad molodshykh spetsialistiv z farmatsevtychnoiu osvitoiu u zakladakh okhorony zdorovia (2002). Nakaz MOZ Ukrainy No. 385. 28.10.2002. Available at: https://zakon.rada.gov.ua/laws/show/z0892-02

[8] Pro zatverdzhennia poriadku formuvannia spromozhnykh merezh nadannia pervynnoi medychnoi dopomohy (2018). Nakaz Ministerstva okhorony zdorovia Ukrainy ta Ministerstva rehionalnoho rozvytku, budivnytstva ta zhytlovo-komunalnoho hospodarstva Ukrainy No. 178/24. 06.02.2018. Available at: https://zakon.rada.gov.ua/laws/show/z0215-18

[9] Deiaki pytannia nadannia medychnoi subventsii z derzhavnoho biudzhetu mistsevym biudzhetam (2015). Postanova Kabinetu Ministriv Ukrainy No. 11. 23.01.2015 (iz zminamy). Available at: http://zakon.rada.gov.ua/laws/show/11-2015- \%D0 \%BF

[10] Stakhurska, O. (2017). Autsorsynh v Ukraini y u sviti: osoblyvosti, tendentsii ta perspektyvy. Yuryst \& zakon, 38. Available at: http://uz.ligazakon.ua/ua/magazine_article/EA010850

[11] Pavlenko, O. (2017). Autsorsynh, autstafinh i lizynh personalu yak zasoby optymizatsii biznes-protsesiv ta zabezpechennia interesiv personalu. Yuryst \& zakon, 38. Available at: http://uz.ligazakon.ua/ua/magazine_article/EA010846

[12] Pro zatverdzhennia Litsenziinykh umov provadzhennia hospodarskoi diialnosti z medychnoi praktyky (2016). Postanova Kabinetu Ministriv Ukrainy No. 285. 02.03.2016. Available at: http://zakon.rada.gov.ua/laws/show/285-2016- \%D0 \%BF

[13] Pro zatverdzhennia Prymirnoho tabelia materialno-tekhnichnoho osnashchennia zakladiv okhorony zdorovia ta fizychnykh osib - pidpryiemtsiv, yaki nadaiut pervynnu medychnu dopomohu (2018). Nakaz MOZ Ukrainy No. 148. 26.01.2018. Available at: http://moz.gov.ua/uploads/0/4141-dn_20180126_148.pdf

[14] Ustynov, A. V. (2017). Formuvannia medychnoi infrastruktury v obiednanykh terytorialnykh hromadakh. Ukrainskyi medychnyi chasopys. Available at: https://www.umj.com.ua/article/107511/formuvannya-medichnoyi-infrastrukturi-v-ob-yednanih-teritorialnih-gromadah

[15] Baieva, O. V. (2008). Menedzhment u haluzi okhorony zdorovia. Kyiv: Tsentr uchbovoi literatury, 640. Available at: https:// studbooks.net/37372/meditsina/menedzhment_v_oblasti_ohrany_zdorovya

[16] Levinskii, D. (2018). Reshitelnaia medicinskaia reforma. Available at: https://tverezo.info/post/51112

[17] Hromady uspishno spivpratsiuiut u sferi okhorony zdorovia. Tsentr politychnykh studii ta analityky EIDOS. Available at: https://eidos.org.ua/novyny/hromady-uspishno-spivpratsyuyut-u-sferi-ohorony-zdorovya/

[18] Andronyk, V. (2017). Medytsyna v sosednykh stranakh y Ukrayne: chto zhdet nashe zdravookhranenye. Available at: https://www.segodnya.ua/lifestyle/food_wellness/medicina-v-sosednih-stranah-i-ukraine-chto-zhdet-nashe-zdravoohranenie-1020294.html 